\title{
Estimating the flux of nitrate in a sandy loam soil under corn
}

\author{
E. Fernández-Boy, F. Cabrera, J.M. Murillo, F. Moreno, J.A. Cayuela \& J.E. Fernández \\ Instituto de Recursos Naturales y Agrobiología de Sevilla, CSIC, Apartado I052, 41080 Sevilla, Spain
}

Key words: Nitrate leaching, monolith lysimeter, water flux, hydraulic conductivity, soil water content

\begin{abstract}
Drainage and nitrate leaching were determined in an undisturbed sandy loam soil contained in two monolith lysimeters (L1 and L2; $1.2 \mathrm{~m}$ deep) cropped with corn, irrigated, and fertilized with 510 and $175 \mathrm{~kg} \mathrm{~N}^{-1}$ in $\mathrm{Ll}$ and L2 respectively. Drainage was estimated at $0.9 \mathrm{~m}$ depth using Darcy's law and the hydraulic conductivity-soil water content relationship. Nitrate leaching at the same depth was obtained multiplying the estimated drainage by the nitrate concentration of the soil solution extracted with suction cups. A comparison between results from measurements at the bottom of lysimeters and that estimated at $0.9 \mathrm{~m}$ depth was made for the whole experimental period (March 1992-February 1993). The $\mathrm{NO}_{3}-\mathrm{N}$ concentrations in the drainage water ranged between 2.8 and 151 $\mathrm{mg} \mathrm{l}^{-1}$ in $\mathrm{L} 1$ and between 0.1 and $34.4 \mathrm{mg}^{-1}$ in $\mathrm{L} 2$. In the soil solution, they ranged between 5.9 and $240.3 \mathrm{mg}$ $\mathrm{NO}_{3}-\mathrm{N} \mathrm{I}^{-1}$ in $\mathrm{L} 1$ and between 0.1 and $42.3 \mathrm{mg} \mathrm{NO}_{3}-\mathrm{N} \mathrm{I}^{-1}$ in L2. The total drainage at the bottom of lysimeters amounted to 139 and $203 \mathrm{~mm}$ and that estimated at $0.9 \mathrm{~m}$ depth amounted to 151 and $245 \mathrm{~mm}$, in L1 and L2 respectively. Total $\mathrm{NO}_{3}-\mathrm{N}$ leached in $\mathrm{LI}$ and $\mathrm{L} 2$ was 80 and $30 \mathrm{~kg} \mathrm{ha}^{-1}$ respectively. The estimated amounts of $\mathrm{NO}_{3}-\mathrm{N}$ leached below 0.9 depth were 64 and $42 \mathrm{Kg} \mathrm{ha}^{-1}$ in L1 and L2 respectively. Total drainage and nitrate leached measured at the bottom were of the same order as the estimated values.
\end{abstract}

\section{Introduction}

In southern Spain, nitrogen management to increase crop yields usually involves high rates of $\mathrm{N}$-fertilizer inputs. The use of $\mathrm{N}$-fertilization rates that exceed the $N$ requirements of crops increases the amounts of potentially leachable nitrate in the soil, and consequently a considerable amount of $\mathrm{N}$-fertilizer can be lost from the soil (Roth and Fox, 1990). The $\mathrm{NO}_{3}$ $N$ leached below the root zone is one of the major pollutants of the groundwater. In large areas leaching of nitrate from agricultural land is the main no-point source for nitrate in groundwater (Duynisveld et al., 1988; Cabrera et al., 1994).

Jolley \& Pierre (1977) sampled long-term corn fertility plots and found that 25 to $46 \%$ of the applied $N$ fertilizer was lost from the soil after the third year of application. Losses of $\mathrm{NO}_{3}-\mathrm{N}$ increase as $\mathrm{N}$ fertilizer rate or amount of subsurface drainage increase (Baker and Timmons, 1994; Fernández-Boy et al., 1994).

Measurement of nitrate losses under field conditions is difficult. For both direct measurement and estimation of nitrate losses, at a depth below the root zone, the water flux draining from the upper layers and the nitrate concentration of this water must be known. Good approaches are (i) the use of monolith lysimeter containing undisturbed soil (Dowdell et al., 1984; Owens, 1990; Bergtröm and Johansson, 1991) in which direct measurement of drainage water and its nitrate concentration is possible; (ii) the water flow, at a determinate depth in the soil, can be estimated using Darcy's law and the relationship between the soil hydraulic conductivity $(\mathrm{K})$ and the soil water content $(\theta)$ determined in situ, and the concentration of nitrate can be determined in the soil solution extracted with suction cups. In both cases, the amount of nitrate leached can be calculated multiplying the amount of drainage water by the concentration of nitrate in this water.

The objective of this study was to determine the nitrate leached under a cropped soil using undisturbed monolith lysimeters. A comparison was also made between the nitrate leached in the drainage water at the bottom of the lysimeter and that estimated below $0.9 \mathrm{~m}$ depth. 


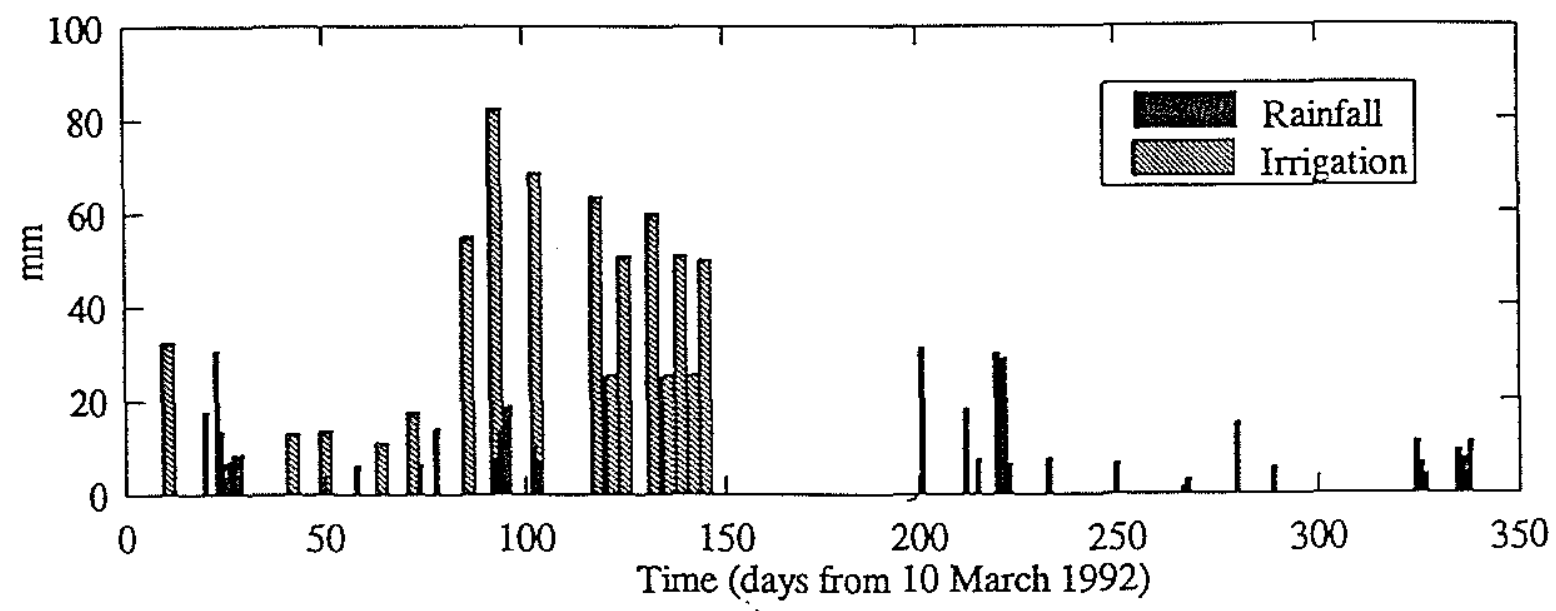

Fig. 1. Rainfall and irrigation during the experiment period

Materials and methods

The experiment on $\mathrm{NO}_{3}-\mathrm{N}$ leaching was conducted from March 1992 until February 1993 in two lysimeters in the Experimental Farm "La Hampa" of the Instituto de Recursos Naturales y Agrobiología de Sevilla (CSIC) in Coria del Rio (province of Seville, SW Spain). The soil of the lysimeters is a sandy loam (Xerochrept; $\mathrm{pH}\left(\mathrm{H}_{2} \mathrm{O}\right) 7.2$ and $7.1 ; \mathrm{CaCO}_{3} 5.2$ and $3.1 \%$; OM 0.88 and $0.69 \%$; Kjeldahl-N 599 and 454 $\mathrm{kg} \mathrm{ha}^{-1} ; \mathrm{NO}_{3}-\mathrm{N} 44$ and $61 \mathrm{~kg} \mathrm{ha}{ }^{-1}$; at $0-0.5$ and $0.5-1.0 \mathrm{~m}$ depth respectively).

Two monolith lysimeters ( $\mathrm{L} 1$ and $\mathrm{L} 2,1 \mathrm{~m}$ in diameter and $1.5 \mathrm{~m}$ deep) were installed in situ without disturbing the soil profile. The lysimeters were provided with a system to collect the drainage water at $1.2 \mathrm{~m}$ depth, an access tube for the neutron probe, two tensiometers at 0.7 and $0.9 \mathrm{~m}$ depth, and a suction cup at $0.9 \mathrm{~m}$ depth. They were sown with corn (Zea mays L., cv. PRISMA (G-4730)) on 24th March 1992 with a density of 75,000 plant ha ${ }^{-1}$. The corn was irrigated following the same schedule as the surrounding plots also cropped with corn. Dates and quantity of irrigation and rainfall are shown in Fig. 1. The total amount of water applied by irrigation was $661 \mathrm{~mm}$. Rainfall was monitored throughout the experimental period (total rainfall $394.5 \mathrm{~mm}$ ). The characteristics of the irrigation water were: E.C. $2.2 \mathrm{dS} \mathrm{m}^{-1} ; \mathrm{NO}_{3}-\mathrm{N} 9.8 \mathrm{mg} \mathrm{l}^{-1}$; Cl $446.6 \mathrm{mg} \mathrm{l}^{-1} ; \mathrm{SO}_{4}-\mathrm{S}_{4} 4.7 \mathrm{mg} \mathrm{l}^{-1}$.

Two different fertilizations were used. L1 received one of the highest $N$-fertilization rates used by farmers of SW Andalucia: a deep fertilization with $1000 \mathrm{~kg}$ $\mathrm{ha}^{-1}$ of 15-15-15 complex NPK fertilizer and two top dressings with $400 \mathrm{~kg} \mathrm{ha}^{-1}$ of urea $(46 \% \mathrm{~N})$, equivalent to ca. $510 \mathrm{~kg} \mathrm{~N}^{-1}$. The fertilization applied to $\mathrm{L} 2$ was one third of that applied to L1: a deep fertilization with $340 \mathrm{~kg} \mathrm{ha}^{-1}$ of complex NPK fertilizer and two top dressing with $130 \mathrm{~kg} \mathrm{ha}^{-1}$ of urea (ca. $170 \mathrm{~kg} \mathrm{~N}$ $\mathrm{ha}^{-1}$ ).

Soil water content was measured periodically with a neutron probe and soil solution was extracted by suction cups and analysed for nitrate content by ionic chromatography using a solution of $0.0013 \mathrm{M}$ borate$0.0013 \mathrm{M}$ gluconate in acetonitrile $(12 \% \mathrm{v} / \mathrm{v})$ at $\mathrm{pH}$ 8.5 as eluent (Waters Ion Chromatography Cookbook, 1989). In addition, leachates were collected and rolumes measured following each rain or irrigation event when they were sufficient to create a leaching. Nitrate was also analysed in drainage water.

Water flow, at $0.9 \mathrm{~m}$ depth in the lysimeter, was estimated using Darcy's law, and the hydraulic conductivity $(\mathrm{K})$-soil water $\operatorname{content}(\theta)$ relationships determined in situ (Cayuela et al., 1994).

\section{Results and discussion}

The concentrations of nitrate in the drainage water collected at the bottom of the lysimeters (1.2 $\mathrm{m}$ depth) ranged between 2.8 and $151 \mathrm{mg} \mathrm{I}^{-1}$ in L1, and between 0.1 and $34.4 \mathrm{mg} \mathrm{l}^{-1}$ in L2. These concentrations were sometimes much higher than the maximum admissible concentration allowed by the EC for drinking water $11.3 \mathrm{mg} \mathrm{NO} \mathrm{N}_{3}-\mathrm{N}^{-1}$ (Council of the European Community, 1980). The cumulative drainage water and the cumulative $\mathrm{NO}_{3}-\mathrm{N}$ leached during the experimental 
Table 1. Cumulative drainage water and nitrate leaching measured at the bottom of the lysimeter (at $1.2 \mathrm{~m}$ depth) and estimated at $0.9 \mathrm{~m}$ depth.

\begin{tabular}{|c|c|c|c|c|c|c|c|c|}
\hline \multirow[t]{3}{*}{ Period } & \multicolumn{4}{|c|}{ drained water $\mathrm{mm}$} & \multicolumn{4}{|c|}{$\mathrm{NO}_{3}-\mathrm{N}$ losses $\mathrm{Kg} \mathrm{ha}^{-1}$} \\
\hline & \multicolumn{2}{|c|}{ measured $1.2 \mathrm{~m}$} & \multicolumn{2}{|c|}{ estimated $0.9 \mathrm{~m}$} & \multicolumn{2}{|c|}{ measured $1.2 \mathrm{~m}$} & \multicolumn{2}{|c|}{ estimated $0.9 \mathrm{~m}$} \\
\hline & $\mathrm{L} 1$ & $\mathrm{~L} 2$ & $\mathrm{~L} 1$ & L2 & $\mathrm{L} 1$ & L2 & $\mathrm{Ll}$ & L2 \\
\hline Crop season & 131 & 137 & 125 & 175 & 77 & 26 & 47 & 35 \\
\hline Dry season & - & 11 & - & - & - & 0.1 & - & - \\
\hline Rainy season & 8 & 55 & 26 & 70 & 3 & 4 & 17 & 7 \\
\hline TOTAL & 139 & 203 & 151 & 245 & 80 & 30 & 64 & 42 \\
\hline
\end{tabular}

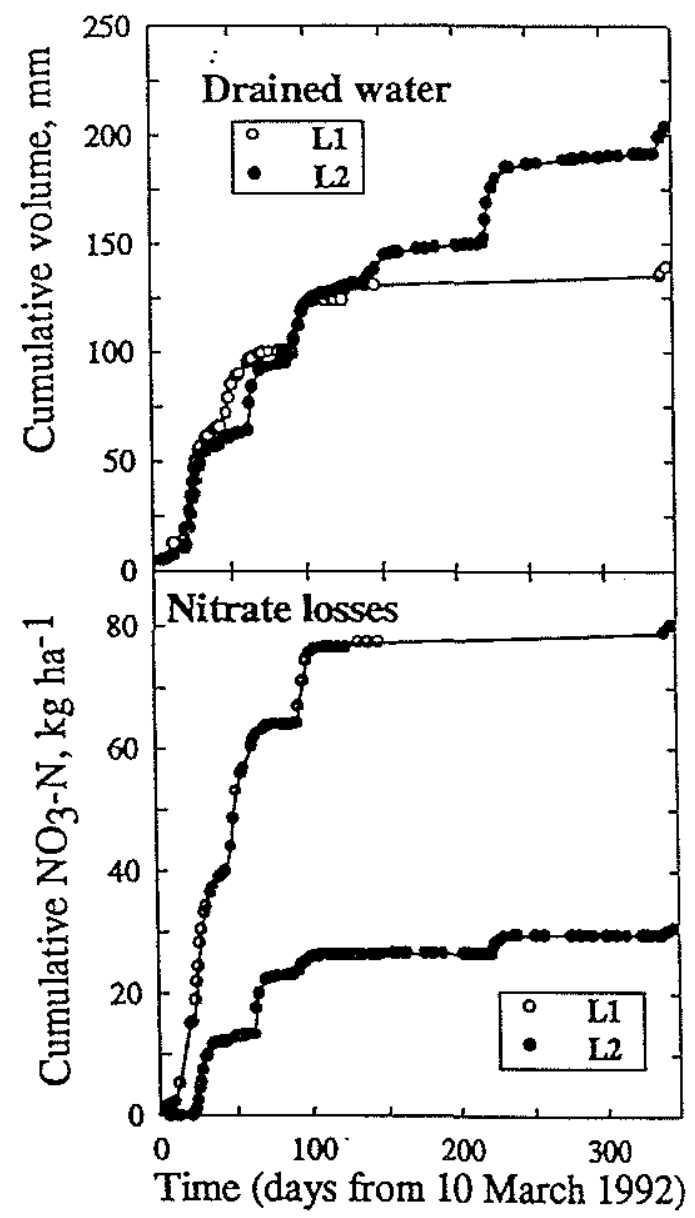

Fig. 2. Cumulative drained water and nitrate losses measured at the bottom of the lysimeters

period, in both lysimeters, are shown in Fig. 2. Three seasons can be distinguished during the experimental period, in the same way as has been reported by
Cabrera et al. (1994) in previous experiments in the same lysimeters: i) 'Crop season' (10 March 1992-11 August 1992); ii) 'Dry season' (11 August 1992-15 September 1992); iii) 'Rainy season' (15 September 1992-21 February 1993) in which the soil was bare. During the 'crop season' the lysimeters received a total of $661 \mathrm{~mm}$ of water by irrigation and $181 \mathrm{~mm}$ by rainfall. In this season the total water drainage was $131 \mathrm{~mm}$ and $137 \mathrm{~mm}$ in $\mathrm{L} 1$ and $\mathrm{L} 2$ respectively (Table 1 ), and the total $\mathrm{NO}_{3}-\mathrm{N}$ leached was 77 and $26 \mathrm{~kg} \mathrm{ha}^{-1}$ in L1 and $L 2$ respectively. The considerable nitrate leaching observed during the early growth period in the crop season (Fig. 2) was due to the rainfall ( $90 \mathrm{~mm}$ ) when the soil was wet from previous irrigations. During the 'dry season' there was practically no drainage, and consequently no leaching of $\mathrm{NO}_{3}-\mathrm{N}$ was observed in $\mathrm{L1}$, and only a very small quantity $\left(0.1 \mathrm{~kg} \mathrm{ha}^{-1}\right)$ in $\mathrm{L} 2$ (Table 1).

During the 'rainy season', in which the lysimeters received $213 \mathrm{~mm}$ of rainfall, the water drainage was 8 and $55 \mathrm{~mm}$ in $\mathrm{L} 1$ and $\mathrm{L} 2$ respectively (Table 1 ). The $\mathrm{NO}_{3}-\mathrm{N}$ leached was 3 and $4 \mathrm{~kg} \mathrm{ha}^{-1}$ in $\mathrm{L} 1$ and $\mathrm{L} 2$ respectively. The drainage observed in $\mathrm{L} 1$ was lower than in L2 due to the fact that at the end of the dry season the soil water content in the deepest layer (0.9$1.2 \mathrm{~m}$ depth) of $\mathrm{L} 1$ was much lower than in L2; thus the hydraulic conductivity was much lower in this layer of L1 than in the same one in L2, as has been shown by Cayuela et al. (1994) for the $\mathrm{K}(\theta)$ function for this soil. Even though the drainage was different in the two lysimeters, the $\mathrm{NO}_{3}-\mathrm{N}$ leached was practically the same, due to the higher $\mathrm{NO}_{3}-\mathrm{N}$ concentrations in the drainage water in L1 than in L2.

The total drainage during the whole period was 139 and $203 \mathrm{~mm}$ in L1 and L2 respectively (Table 1), and 


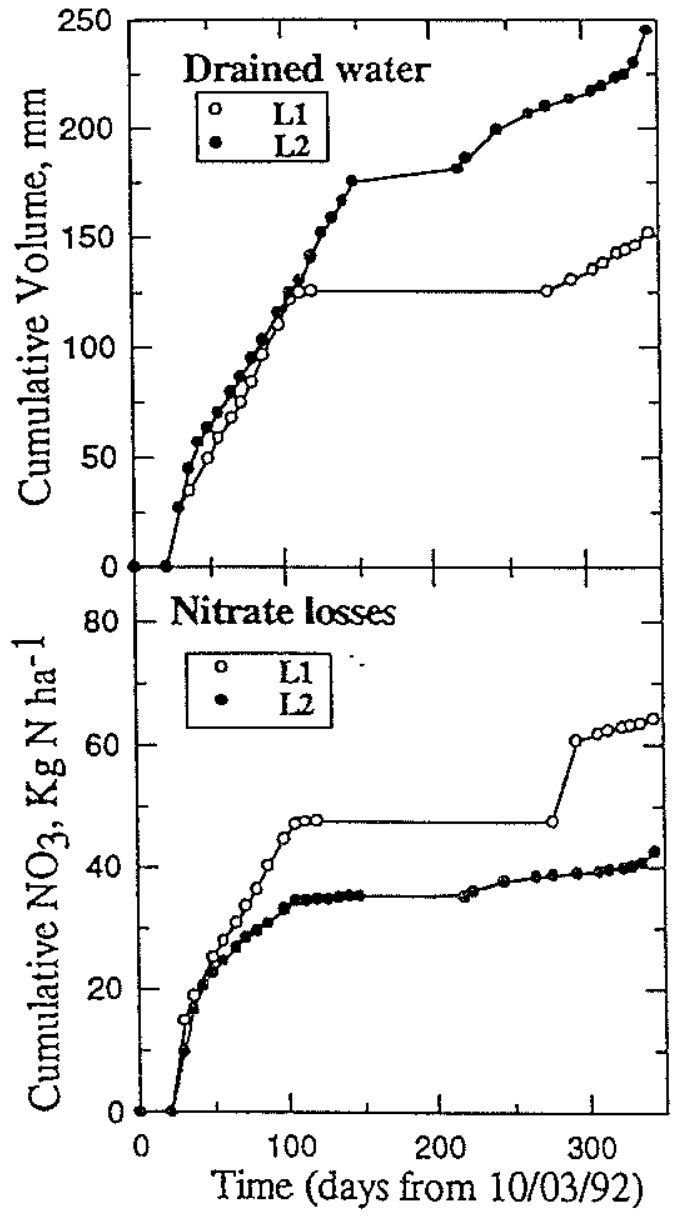

Fig. 3. Cumulative drained water and nitrate losses estimated at $0.9 \mathrm{~m}$ depth

the total $\mathrm{NO}_{3}-\mathrm{N}$ leached was 80 and $30 \mathrm{~kg} \mathrm{ha}^{-1}$ in $\mathrm{L} 1$ and $\mathrm{L} 2$ respectively.

Nitrate concentrations in the soil solution at $0.9 \mathrm{~m}$ depth were always higher in L1 than in L2. These concentrations ranged between 5.9 and $240.3 \mathrm{mg} \mathrm{NO}_{3}$ $\mathrm{N}^{-1}$ in $\mathrm{Ll}$, and between 0.1 and $42.3 \mathrm{mg} \mathrm{NO} 3-\mathrm{N}^{-1}$ in $\mathrm{L} 2$. The cumulative drainage and $\mathrm{NO}_{3}-\mathrm{N}$ leached below $0.9 \mathrm{~m}$ depth are shown in Fig. 3. These results show similar patterns to those obtained at the bottom of the lysimeters (Fig. 2).

Considering the same three seasons mentioned above, the drainage estimated at $0.9 \mathrm{~m}$ depth during the 'crop season' amounted to $137 \mathrm{~mm}$ and $175 \mathrm{~mm}$ in L1 and L2 respectively (Table 1). In the case of L1 the estimated drainage is practically the same as that measured at the bottom of the lysimeter. In contrast, for L2 the estimated drainage was higher than that measured at the bottom. The $\mathrm{NO}_{3}-\mathrm{N}$ leached esti- mated from the water flow and the concentration of the soil solution amounted to 47 and $35 \mathrm{~kg} \mathrm{ha}^{-1}$ in $\mathrm{Ll}$ and L2 respectively. In the case of $\mathrm{L} 1$ the estimated value is much lower than that measured at the bottom. This may be due to the leaching of the residual $\mathrm{NO}_{3}-\mathrm{N}$ from the fertilization of the previous year (Cabrera et al., $1993)$ in the deepest layer (0.9-1.2 m depth). During the autumn-winter period of 1991-1992 the rainfall was very low and the observed drainage was also very low. This did not occur in L2 because no fertilization was applied to this lysimeter in the previous year.

During the 'dry season', drainage and $\mathrm{NO}_{3}-\mathrm{N}$ leaching were not observed at $0.9 \mathrm{~m}$ depth, which agrees with the results at the bottom of the lysimeters (Table 1). In the case of the 'rainy season' the estimated drainage (Table 1) followed the same pattern as at the bottom of the lysimeters, but with higher values in both lysimeters.

\section{Conclusions}

The results obtained in this study show that in an irrigated corn crop, in SW Spain, a strong reduction in the $\mathrm{N}$-fertilization rate used by farmers produces a considerable decrease in nitrate leaching. The volumes of drainage water measured at the bottom of the lysimeters (1.2 $\mathrm{m}$ depth) are of the same order as those estimated at $0.9 \mathrm{~m}$ depth using Darcy's law and the hydraulic conductivity-soil water content relationship. In both lysimeters the amount of nitrate leached at the bottom of the lysimeters agrees with the estimated amount of nitrate leached below $0.9 \mathrm{~m}$ depth.

\section{Acknowledgement}

Research carried out in the framework of the contract No. STEP-CT90-0032 of the C.E.

\section{References}

Baker JL and Timmons DR (1994) Fertilizer management effects on leaching of labeled nitrogen for no-tillage corn in field lysimeters. J Environ Qual 23: 305-310.

Bergtröm L. and Johansson R (1991) Leaching of nitrate from monolith lysimeters of different types of agricultural soils. $J$ Environ Qual 20: 801-807.

Cabrera F, Fernández-Boy E, Aparicio M.G, Murillo JM and Moreno $F$ (1995) Leaching of nitrate from a sandy loam soil under com and two $N$-fertilizations. Fresenius Environ Bull 4: 250-255. 
Cabrera F, Reyes A, Fernández-Boy E, Cayuela JA, Murillo JM and Moreno $F(1993)$ Losses of nitrate on a sandy loam soil under com: lysimeter experiment. Acta Horticulturae 335: 59-64.

Cayuela JA, Femández JE, Moreno F, Moreno JM and Cabrera F (1994) Estimación de las perdidas de nitrato en un suelo con cultivo de maíz y riego. Riego y Drenajes XXI 75: 30-34.

Council of the European Community. Council Directive of 15 July $198080 / 778 / E E C$. Official Joumal of the European Community 1980, L229 11-29.

Duynisveld WHM, Strebel O and Böttcher J (1988) Are nitrate leaching from arable land and nitrate pollution of ground water avoidable? Ecol Bull 39: 116-125.

Dowdell RJ, Webster CP, Hill D, and Mercer ER (1984) A lysimeter study of the fate of nitrogen in spring barley crops grown on a shallow soil overlying Chalk: crop uptake and leaching losses. J Soil Sci 35: 183-190.
Fernández Boy E, Aparicio MG, Cabrera F, Murillo JM and Moreno $F$ (1994) Lixiviado de nitrato en un suelo francoarenoso cultivado de maiz bajo riego y dos fertilizaciones. Riegos y Drenajes XXI 74: $8-13$.

Jolley VD and Pierre WH (1977) Profile accumulation of fertilizerderived nitrate and total nitrogen recovery in two long-tern nitrogen ratc experiment with com. Soil Sci Soc Am J 41: 373-378.

Owens LB (1990) Nitrate-nitrogen concentration in percolate from lysimeters planted to a legume-grass mixture. J Environ Qual 19: 131-135.

Roth LW and Fox RH (1990) Soil nitrate accumulations following nitrogen-fertilized com in Pennsylvania. J Environ Qual 19: 131135.

Smith SJ, Schepers JS and Porter KL (1990) Assessing and managing agricultural nitrogen losses to the environment. Adv Soil Sci 14: $1-43$.

Waters Ion Chromatography Cookbook (1989) Waters, Millipore, Milford, Massachusetts. 